\title{
THEORETICAL INVESTIGATION OF A NOVEL SOLAR STILL CONFIGURATION FOR ENHANCED HIGH-QUALITY DRINKING WATER PRODUCTION
}

\author{
MARIEM JOBRANE ${ }^{1,2}$, ADEL KHARROUBI $^{3}$, ALIZA KAHN $^{4}$, \\ ACHIM KOPMEIER $^{5}$ \& CHRISTIAN PENNY ${ }^{1}$ \\ ${ }^{1}$ Luxembourg Institute of Science and Technology (LIST), Luxembourg \\ ${ }^{2}$ National School of Engineers, Gabès University, Tunisia \\ ${ }^{3}$ Higher Institute of the Sciences and Techniques of Waters of Gabès, Gabès University, Tunisia \\ ${ }^{4}$ Jiddereen Sàrl, Luxembourg \\ ${ }^{5}$ Myriado Sàrl, Luxembourg
}

\begin{abstract}
Lack of safe and reliable drinking water constitutes a major problem due to a rising worldwide population, global socio-economic development, increasing environmental pressure and climate change. Hence, solar distillation technology for drinking water production presents a conceivable solution for reducing the global water stress. The method requires low capital investment, low maintenance and no energy cost. However, the yield is generally limited. This paper proposes a new solar still configuration using an alternative mode of condensation and thermodynamics. The new solar still was designed to increase the productivity and to improve the efficiency of the conventional solar still. A theoretical study is developed based on a mathematical modelling approach and aims to investigate the performance of the new concept. The obtained results using Matlab software were compared to the conventional solar still system. It has been found that the daily productivity enhancement of the proposed system is around $68 \%$ compared to the simple device. An optimization procedure of the proposed solar still was performed in this study based on the design of experiment technique (DoE) using Taguchi approach.
\end{abstract}

Keywords: solar still, solar energy, design, modelling, simulation, productivity, microcontroller, design of experiment, Taguchi method.

\section{INTRODUCTION}

Nowadays millions people do not have access to a secure source of fresh water. Though the availability of global water reserves is about 1.4 billon $\mathrm{km}^{3}$, where the seawater constitutes about $97 \%$ and only $3 \%$ is fresh water [1]. Therefore, seawater desalination processes prove to be a suitable alternative for the drinking water crisis. The use of renewable energies in desalination processes exhibits an interesting chance to supply the local population with fresh water. The solar still is a viable process, economical and simple device used for water purification, especially in remote and rural areas. In order to improve its productivity and efficiency, some researchers introduced modified geometries of solar stills, such as, tubular stills [2], vertical stills [3], hemi-spherical stills [4], solar stills with internal and external reflectors [5], with additional condenser [6], multiple-stage stills [7], and wick type stills [8], etc.

The present study aims to describe a new configuration of solar still device and highlight the improvements made in design and in thermodynamic process. Combining the two ideas of enhancing the productivity of the solar still and maintaining the simplicity and the low cost is expected to yield an economically viable design for a solar still. A theoretical study based on mathematical modelling has been developed using a meteorological data of a typical summer day in Northern Africa. In order to validate the analysis results, an experimental investigation of the new system will be involved afterwards. As a preparatory step for the experimental approach, a design of experiments method (DoE) based on Taguchi 
methodology is applied with the aim of effectively creating an experimentation strategy that will help in investigating the influence of multiple variables simultaneously on the solar still's performance with a reduced number of experiments.

\section{DESCRIPTION OF THE NEW SOLAR STILL CONFIGURATION}

Recently, the higher productivity of solar stills is the focus of intensive research [9]. Many studies have found that the best yield is achieved based on increasing the evaporating and condensation processes and on reducing the heat losses to the ambient [9]. In this study, an interesting new enhancement on the solar still's design and materials is introduced for testing, with the aim of overcoming the limited productivity problem. The new configuration of the solar still consists of a tray with black porous wick, which is continuously soaked with saline water. Through this wick, the feed water slowly flows and then, it is heated and evaporated once receiving the solar radiation. The main improvement in this new setup is the implementation of a modified condensation process, which reduce the heat loss from the solar still to the atmosphere and raise the evaporation rate for high water vapour production. The condensation heat loss is reduced by moving the produced water vapor from the outer skin of the still to the inside and transferring the condensation heat to the raw-water. Hence, the solar still will be divided into two parts by the tray where the feed water is flowed as shown in Fig. 1. The water vapor transfer is achieved through forced convection by using a simple fan and it is condensed against the under-side of the tray. The recovered heat underneath the tray increases the temperature of the brine water and it is available to support the evaporation process. Besides, the key to greater productivity of this new solar still system is the identification of the optimal working point, which should be automatically maintained. This working point is characterised by a feed-rate of the brine and the circulation rate of the vapor. Hence, a microcontroller is installed and programmed in order to automatically operate the pump for the brine water flow and control the fan speed installed under the tray. Furthermore, a system of sensors (temperature, humidity, salinity, solar intensity) is defined to continuously monitor the internal and external conditions of the still. Based on the information collected by this system, the set-point of the still will be shifted to keep it constantly at the optimum.

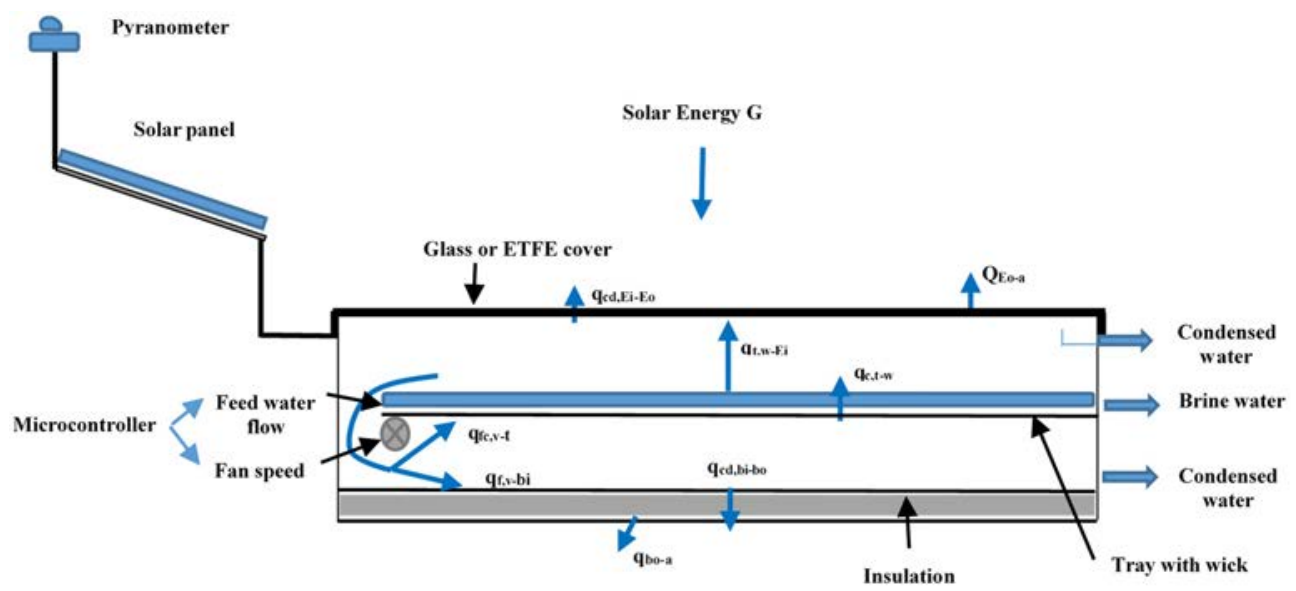

Figure 1: Schematic diagram of the new proposed solar still. 
The enhancement of the solar still productivity can also be performed by an optimum selection of the top transparent cover characteristics, such as, type of material and thickness. Glass has been the traditional transparent cover material used by most of solar distillation units over the world. The main advantage of glass is that it is cheap and widely available, however, it is also heavy and has a high potential for breakage, making it unsuitable and unsafe for some installation. Fluoropolymer material, such as, ETFE (Ethylene Tetra-FluoroEthylene) foil represents a promoting alternative for a lightweight top cover, which is available to replace glass in the new setup. The ETFE foil is a co-polymer of Ethylene and Teflon, which was widely used in the construction industry as roofing material [10]. This great material transmits between 94 and $97 \%$ of visible light [11]. However, a $6 \mathrm{~mm}$ glazing can only transmit $89 \%$ of visible light [11]. Furthermore, a typical ETFE film has a weight of approximately $175 \mathrm{~g} / \mathrm{m}^{2}$ for a film thickness of 100 microns [12]; hence, it can be applied as a double layer for increased thermal efficiency without a major increase in the still's weight. The new improved solar still described above is proposed for testing in order to ensure more efficiency, the high productivity and good quality of the produced drinking water.

\section{THEORETICAL ANALYSIS OF THE NEW SOLAR STILL}

Numerous researches introduced a series of thermal analysis and mathematical modelling as well as thermodynamic balances with the purpose of investigating the productivity of the solar still [13]. The first thorough research of solar still modelling was published by Dunkle in 1961. Dunkle provided a theoretical overview of roof type solar stills by highlighting the heat and mass transfer relationships [14]. Based on the Dunkle's relations, many investigations on solar still with different designs and modifications have been carried out by researchers over years. In this section, a theoretical investigation of the new improved concept is presented based on a mathematical modelling approach. The internal and external heat transfer phenomena are evaluated. The energetic analysis is developed in order to compare the performance of the conventional solar still with the new system. The energy balance equations are written for various parts of the solar still, such as ETFE cover, water mass, tray and basin liner.

\subsection{Energy balance of the outer ETFE cover}

The outer surface of ETFE cover receives the energy from the incident solar radiation and from the inner surface by conduction. The heat is lost from the outer skin of ETFE cover to the atmosphere by convection and radiation

$$
\begin{gathered}
\alpha_{\mathrm{E}}^{\prime} \mathrm{G}(\mathrm{t})+\mathrm{q}_{\mathrm{cd}, \mathrm{Ei}-\mathrm{Eo}}=\mathrm{q}_{\mathrm{c}, \mathrm{Eo}-\mathrm{a}}+\mathrm{q}_{\mathrm{r}, \mathrm{Eo}-\mathrm{a}}, \\
\alpha_{\mathrm{E}}^{\prime} \mathrm{G}(\mathrm{t})+\frac{\mathrm{k}_{\mathrm{E}}}{\mathrm{e}_{\mathrm{E}}}\left(\mathrm{T}_{\mathrm{Ei}}-\mathrm{T}_{\mathrm{Eo}}\right)=\mathrm{h}_{\mathrm{Ea}}^{\prime}\left(\mathrm{T}_{\mathrm{Eo}}-\mathrm{T}_{\mathrm{a}}\right), \\
\mathrm{T}_{\mathrm{Eo}}=\frac{\alpha_{\mathrm{E}}^{\prime} \mathrm{G}(\mathrm{t})+\frac{\mathrm{k}_{\mathrm{E}}}{\mathrm{e}_{\mathrm{E}}} \mathrm{T}_{\mathrm{Ei}}+\mathrm{h}_{\mathrm{Ea}}^{\prime} \mathrm{T}_{\mathrm{a}}}{\frac{\mathrm{k}_{\mathrm{E}}}{\mathrm{e}_{\mathrm{E}}}+\mathrm{h}_{\mathrm{Ea}}^{\prime}} .
\end{gathered}
$$

The fraction of solar radiation absorbed by the ETFE is given by [15],

$$
\alpha_{\mathrm{E}}^{\prime}=\left(1-\mathrm{R}_{\mathrm{E}}\right) \alpha_{\mathrm{E}} \text {. }
$$

The global heat exchange coefficient from ETFE to ambient, h'Ea, is given by [16],

$$
\mathrm{h}_{\mathrm{Ea}}^{\prime}=\mathrm{h}_{\mathrm{c}, \mathrm{Ea}}+\mathrm{h}_{\mathrm{r}, \mathrm{Ea}} .
$$


The coefficient of heat convective transfer between ETFE and sky, $\mathrm{h}_{\mathrm{c}, \mathrm{Ea}}$, is given by [17],

$$
\mathrm{h}_{\mathrm{c}, \mathrm{Ea}}=2.8+3 \mathrm{~V} \text {. }
$$

The radiative heat transfer coefficient between ETFE and sky, $\mathrm{h}_{\mathrm{r}, \mathrm{Ea}}$, is given by [17],

$$
\mathrm{h}_{\mathrm{r}, \mathrm{Ea}}=\frac{\varepsilon \sigma\left(\left(\mathrm{T}_{\mathrm{Eo}}+273\right)^{4}-\left((\mathrm{Ts}+273)^{4}\right)\right.}{\left(\mathrm{T}_{\mathrm{Eo}}-\mathrm{Ts}\right)} .
$$

The effective sky temperature, Ts, is given by [13],

$$
\mathrm{Ts}=\mathrm{Ta}-6 .
$$

\subsection{Energy balance of the inner ETFE cover}

The inner surface of the ETFE cover receives the energy from the water surface by convection, evaporation and radiation. A part of heat is stored in the ETFE cover due to its specific heat and the remaining heat is passed by conduction to the outer surface.

$$
\begin{aligned}
& \mathrm{q}_{\mathrm{t}, \mathrm{w}-\mathrm{Ei}}=\left(\mathrm{e}_{\mathrm{E}} \rho_{\mathrm{E}} \mathrm{Cp}_{\mathrm{E}} \frac{\mathrm{dT}_{\mathrm{Ei}}}{\mathrm{dt}}\right)+\mathrm{q}_{\mathrm{cd}, \mathrm{Ei}-\mathrm{Eo}}, \\
& \frac{\mathrm{dT}_{\mathrm{Ei}}}{\mathrm{dt}}=\frac{1}{\mathrm{e}_{\mathrm{E}} \rho_{\mathrm{E}} \mathrm{Cp}_{\mathrm{E}}}\left(\mathrm{h}_{\mathrm{wE}}^{\prime}\left(\mathrm{T}_{\mathrm{w}}-\mathrm{T}_{\mathrm{Ei}}\right)-\frac{\mathrm{k}_{\mathrm{E}}}{\mathrm{e}_{\mathrm{E}}}\left(\mathrm{T}_{\mathrm{Ei}}-\mathrm{T}_{\mathrm{Eo}}\right)\right) .
\end{aligned}
$$

The global heat exchange coefficient from water to ETFE cover, $\mathrm{h}_{\mathrm{wE}}$, is defined as following,

$$
\mathrm{h}_{\mathrm{wE}}^{\prime}=\mathrm{h}_{\mathrm{c}, \mathrm{wE}}+\mathrm{h}_{\mathrm{e}, \mathrm{wE}}+\mathrm{h}_{\mathrm{r}, \mathrm{We}} \text {. }
$$

The convective heat transfer coefficient, $\mathrm{h}_{\mathrm{c}, \mathrm{wE}}$, is given by [16],

$$
\mathrm{h}_{\mathrm{c}, \mathrm{wE}}=0.884\left(\left(\mathrm{~T}_{\mathrm{w}}-\mathrm{T}_{\mathrm{Ei}}\right)+\frac{\left(\mathrm{P}_{\mathrm{w}}-\mathrm{P}_{\mathrm{Ei}}\right)\left(\mathrm{T}_{\mathrm{w}}+273.15\right)}{268.9 \times 10^{3}-\mathrm{P}_{\mathrm{w}}}\right)^{1 / 3} .
$$

The evaporative heat transfer coefficient, $\mathrm{h}_{\mathrm{e}, \mathrm{wE}}$, is given by [16],

$$
h_{e, w E}=16.276 \times 10^{-3} h_{c, w E}\left(\frac{P_{w}-P_{E i}}{T_{w}-T_{E i}}\right) .
$$

The radiative heat transfer coefficient, $\mathrm{h}_{\mathrm{r}, \mathrm{wE}}$, is given by [16],

$$
\mathrm{h}_{\mathrm{r}, \mathrm{wE}}=\varepsilon \sigma\left(\left(\mathrm{T}_{\mathrm{w}}+273\right)^{2}+\left(\mathrm{T}_{\mathrm{Ei}}+273\right)^{2}\right)\left(\mathrm{T}_{\mathrm{w}}+\mathrm{T}_{\mathrm{Ei}}+546\right) .
$$

The partial saturated vapor pressure at different temperatures, $\mathrm{P}_{\mathrm{i}}$, is given by [16],

$$
\mathrm{P}_{\mathrm{i}}=\exp \left(25.317-\frac{5144}{\left.\mathrm{~T}_{\mathrm{i}}+273\right)}\right) .
$$

\subsection{Energy balance of the water mass}

Heat energy is absorbed by the water due to the fraction of transmitted solar radiation striking on it and due to the transferred heat from the tray by convection. The received energy is consumed in two ways, a part of the heat is stored in water due to its specific heat, and the other part is transferred from water to the inner ETFE cover by convection, radiation and evaporation

$$
\begin{aligned}
& \alpha^{\prime}{ }_{w} G(t)+q_{c, t-w}=\left(e_{w} \rho_{w} C_{w} \frac{d^{2} T_{w}}{d t}\right)+q_{t, w-E i}, \\
& \frac{\mathrm{dT}_{\mathrm{w}}}{\mathrm{dt}}=\frac{1}{\mathrm{e}_{\mathrm{w}} \rho_{\mathrm{w}} \mathrm{Cp}_{\mathrm{w}}}\left(\alpha_{\mathrm{w}}^{\prime} \mathrm{G}(\mathrm{t})+\mathrm{h}_{\mathrm{c}, \mathrm{tw}}\left(\mathrm{T}_{\mathrm{t}}-\mathrm{T}_{\mathrm{w}}\right)-\mathrm{h}^{\prime}{ }_{\mathrm{wE}}\left(\mathrm{T}_{\mathrm{w}}-\mathrm{T}_{\mathrm{Ei}}\right)\right) \text {. }
\end{aligned}
$$


The fraction of solar radiation absorbed by water is given by [15],

$$
\alpha_{\mathrm{w}}^{\prime}=\left(1-\alpha_{\mathrm{E}}\right)\left(1-\mathrm{R}_{\mathrm{E}}\right)\left(1-\mathrm{R}_{\mathrm{w}}\right) \alpha_{\mathrm{w}} \text {. }
$$

The convective heat transfer coefficient between tray and water, $\mathrm{h}_{\mathrm{c}, \mathrm{tw}}$, is given by [16],

$$
\mathrm{h}_{\mathrm{c}, \mathrm{tw}}=\frac{\mathrm{Nu} \cdot \mathrm{k}}{\mathrm{L}} \text {. }
$$

For the natural convection, Nusselt number $\mathrm{Nu}$ is given by [18],

$$
\begin{array}{cc}
\mathrm{Nu}=0.54 \mathrm{Ra}^{1 / 4} & \text { For, } 10^{5}<\mathrm{Ra}<2 \times 10^{7}, \\
\mathrm{Nu}=0.15 \mathrm{Ra}^{1 / 3} & \text { For, } 2 \times 10^{7}<\mathrm{Ra}<3 \times 10^{10} .
\end{array}
$$

\subsection{Energy balance of the tray}

The tray received the heat energy from the absorbed solar radiation and from the transmitted water vapor by forced convection using the fan. A part of the absorbed heat is stored in the tray and the remaining heat is transferred by convection to the water mass

$$
\begin{gathered}
\alpha_{t}^{\prime} G(t)+q_{f c, v-t}=\left(e_{t} \rho_{t} C p_{t} \frac{d T_{t}}{d t}\right)+q_{c, t-w}, \\
\frac{d T_{t}}{d t}=\frac{1}{e_{t} \rho_{t} C p_{t}}\left(\alpha_{t}^{\prime} G(t)+h_{f c, v t}\left(T_{v}-T_{t}\right)-h_{c, t w}\left(T_{t}-T_{w}\right)\right) .
\end{gathered}
$$

The fraction of solar radiation absorbed by the tray is given by [15],

$$
\alpha_{\mathrm{t}}^{\prime}=\left(1-\alpha_{\mathrm{E}}\right)\left(1-\mathrm{R}_{\mathrm{E}}\right)\left(1-\alpha_{\mathrm{w}}\right)\left(1-\mathrm{R}_{\mathrm{w}}\right) \alpha_{\mathrm{t}} .
$$

Air-water vapor mixture temperature, $\mathrm{T}_{\mathrm{v}}\left({ }^{\circ} \mathrm{C}\right)$, is assumed to be the arithmetic mean value of water and inner ETFE cover temperatures [17]

$$
\mathrm{T}_{\mathrm{v}}=\frac{\mathrm{T}_{\mathrm{W}}+\mathrm{T}_{\mathrm{Ei}}}{2} .
$$

The heat transfer coefficient by forced convection between water vapor and tray, $\mathrm{h}_{\mathrm{fc}, \mathrm{vt}}$, is given by [19],

$$
\mathrm{h}_{\mathrm{fc}, \mathrm{vt}}=\frac{\text { Nu.k }}{\mathrm{L}} .
$$

For flow over flat plate and for forced convection, Nusselt number $\mathrm{Nu}$ is given by [19],

$$
\mathrm{Nu}=0.023 \operatorname{Re}^{0.8} \operatorname{Pr}^{0.4} \text {. }
$$

\subsection{Energy balance of inner basin liner}

The inner surface of the basin receives the heat energy from the transmitted water vapor by forced convection and evaporation. The absorbed heat energy is stored into the basin and the remaining heat is passed to the outer skin by conduction

$$
\begin{gathered}
\mathrm{q}_{\mathrm{f}, \mathrm{v}-\mathrm{bi}}=\left(\mathrm{e}_{\mathrm{b}} \rho_{\mathrm{b}} \mathrm{Cp}_{\mathrm{b}} \frac{\mathrm{dT}_{\mathrm{bi}}}{\mathrm{dt}}\right)+\mathrm{q}_{\mathrm{cd}, \mathrm{bi}-\mathrm{bo}}, \\
\frac{\mathrm{dT}_{\mathrm{bi}}}{\mathrm{dt}}=\frac{1}{\mathrm{e}_{\mathrm{b}} \rho_{\mathrm{b}} \mathrm{Cp}_{\mathrm{b}}}\left(\mathrm{h}_{\mathrm{f}, \mathrm{vbi}}\left(\mathrm{T}_{\mathrm{v}}-\mathrm{T}_{\mathrm{bi}}\right)-\frac{\mathrm{k}_{\mathrm{i}}}{\mathrm{e}_{\mathrm{i}}}\left(\mathrm{T}_{\mathrm{bi}}-\mathrm{T}_{\mathrm{bo}}\right)\right) .
\end{gathered}
$$

The global heat exchange coefficient from water vapor and the inner basin liner, $\mathrm{h}_{\mathrm{f}, \mathrm{v}-\mathrm{bi}}$, is the sum of the forced convective heat transfer coefficient, $\mathrm{h}_{\mathrm{fc}, \mathrm{vbi}}$, and the evaporation heat transfer coefficient, $h_{\text {fe,vbi }}$ 


$$
\mathrm{h}_{\mathrm{f}, \mathrm{v}-\mathrm{bi}}=\mathrm{h}_{\mathrm{fc}, \mathrm{vbi}}+\mathrm{h}_{\mathrm{fe}, \mathrm{vb}},
$$

where, the forced convective heat transfer coefficient, $\mathrm{h}_{\mathrm{fc}, \mathrm{vbi}}$, is calculated the same way as $\mathrm{h}_{\mathrm{fc}, \mathrm{vt}}$. Furthermore, the evaporation heat transfer coefficient between water vapor and tray, $\mathrm{h}_{\mathrm{fe}, \mathrm{v}}$, is given by [16],

$$
\mathrm{h}_{\mathrm{fe}, \mathrm{vbi}}=16.276 \times 10^{-3} \mathrm{~h}_{\mathrm{hfc}, \mathrm{vbi}}\left(\frac{\mathrm{P}_{\mathrm{v}}-\mathrm{P}_{\mathrm{bi}}}{\mathrm{T}_{\mathrm{v}}-\mathrm{T}_{\mathrm{bi}}}\right) .
$$

\subsection{Energy balance of outer basin liner}

The heat energy passed by conduction from the inner basin liner is lost to the ambient by conduction

$$
\begin{gathered}
\mathrm{q}_{\mathrm{cd}, \mathrm{bi}-\mathrm{bo}}=\mathrm{q}_{\mathrm{bo}-\mathrm{a}}, \\
\frac{\mathrm{k}_{\mathrm{i}}}{\mathrm{e}_{\mathrm{i}}}\left(\mathrm{T}_{\mathrm{bi}}-\mathrm{T}_{\mathrm{bo}}\right)=\mathrm{U}_{\mathrm{ba}}\left(\mathrm{T}_{\mathrm{bo}}-\mathrm{T}_{\mathrm{a}}\right), \\
\mathrm{T}_{\mathrm{bo}}=\frac{\frac{\mathrm{k}_{\mathrm{i}}}{\mathrm{e}_{\mathrm{i}}} \mathrm{T}_{\mathrm{bi}}+\mathrm{U}_{\mathrm{ba}} \mathrm{T}_{\mathrm{a}}}{\frac{\mathrm{k}_{\mathrm{i}}}{\mathrm{e}_{\mathrm{i}}}+\mathrm{U}_{\mathrm{ba}}} .
\end{gathered}
$$

The overall external heat loss coefficient from bottom to the atmosphere is given by [15],

$$
\mathrm{U}_{\mathrm{ba}}=\frac{1}{\frac{\mathrm{kb}}{\mathrm{eb}}+\frac{1}{\mathrm{~h}_{\mathrm{ba}}}} .
$$

The total heat transfer coefficient from basin liner to ambient, $\mathrm{h}_{\mathrm{ba}}$, is given by [16],

$$
\begin{gathered}
\mathrm{h}_{\mathrm{ba}}=\mathrm{h}_{\mathrm{c}, \mathrm{ba}}+\mathrm{h}_{\mathrm{r}, \mathrm{ba}}, \\
\mathrm{h}_{\mathrm{ba}}=(2.8+3 \mathrm{~V})+\left(\frac{\varepsilon g \sigma\left(\left(\mathrm{T}_{\mathrm{bo}}+273\right)^{4}-\left(\left(\mathrm{T}_{\mathrm{s}}+273\right)^{4}\right)\right.}{\left(\mathrm{T}_{\mathrm{bo}}-\mathrm{T}_{\mathrm{s}}\right)}\right) .
\end{gathered}
$$

\subsection{Distillate water production and hourly efficiency}

The mass of distillate water per unit area per unit of time could be defined as the ratio of the evaporation rate, and the latent heat of water vaporization [13]. Owing to the recycled water vapor under the tray in the new system, a second condensation process is taking place on the bottom of the solar still. Therefore, the mass of distillate water is calculated as following

$$
\dot{\mathrm{m}}_{\mathrm{ew}}=\frac{\mathrm{h}_{\mathrm{e}, \mathrm{wE}}\left(\mathrm{T}_{\mathrm{w}}-\mathrm{T}_{\mathrm{Ei}}\right)+\mathrm{h}_{\mathrm{fe}, \mathrm{vbi}}\left(\mathrm{T}_{\mathrm{v}}-\mathrm{T}_{\mathrm{bi}}\right)}{\mathrm{L}_{\mathrm{ev}}} \text {. }
$$

The hourly efficiency of the solar still is determined by the following expression [13],

$$
\eta=\frac{\text { mew Lev }}{G(t) \times 3600} \text {. }
$$

\section{RESULTS OF THE THERMAL MODELLING AND DISCUSSION}

The aforementioned nonlinear ordinary differential equations are resolved based on a computer simulation program with the assistance of Matlab software. The diverse temperatures are evaluated and the hourly yield variation is computed relying on the meteorological data of a typical summer day in Northern Africa (Tunisia) between 6:00 am and 7:00 pm. Fig. 2 illustrates the hourly variation in the temperatures of water, tray, inner and outer ETFE cover, inner and outer basin liner. All the temperature curves show the same 
shape depending on the solar intensity variation during the day. All the temperatures increase during the morning until they reach the maximum between 12:00 am and 3:00 pm, than they decrease gradually. The theoretical results indicate that the hourly variation of the water and tray temperatures almost coincide each other. It is due to the fact that the water flows slowly through the wick, thus, the depth of the water is very low. Furthermore, it is clearly observed that, there is a high temperature difference between the inner and the outer ETFE cover. These results could be explained by the good thermal properties of the ETFE material used as a transparent cover.

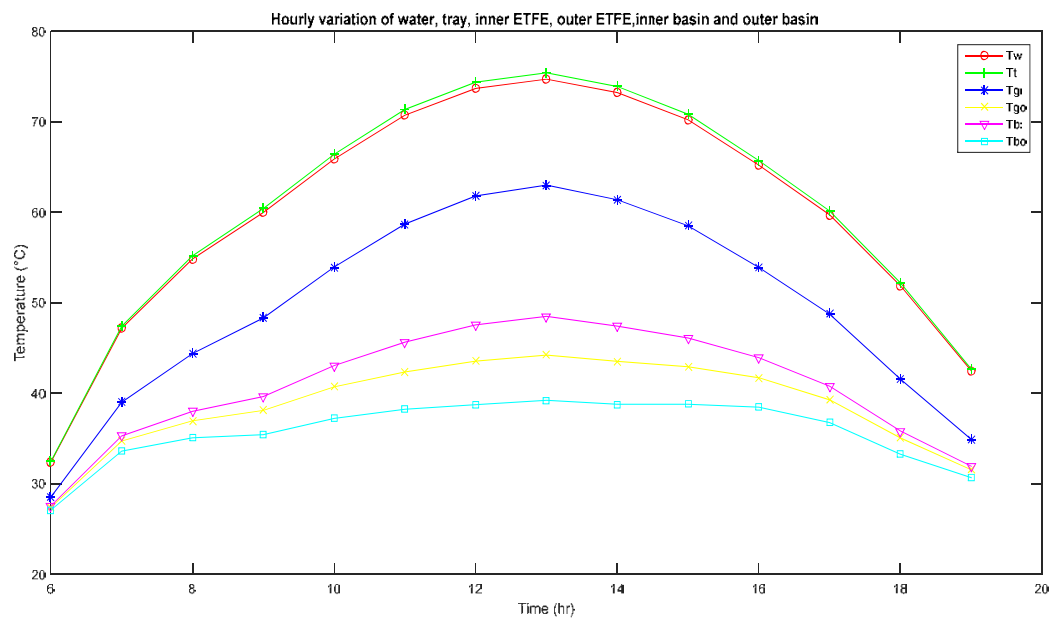

Figure 2: Hourly temperature variation of water $\left(\mathrm{T}_{\mathrm{w}}\right)$, tray $\left(\mathrm{T}_{t}\right)$, inner cover $\left(\mathrm{T}_{\mathrm{gi}}\right)$, outer cover $\left(\mathrm{T}_{\mathrm{go}}\right)$, inner basin $\left(\mathrm{T}_{\mathrm{bi}}\right)$ and outer basin liner $\left(\mathrm{T}_{\mathrm{bo}}\right)$.

Similar results are also obtained for the inner and the outer surfaces of the basin liner. The temperature difference between the two surfaces is the result of using a thermal insulation with thickness of $e_{i}=5 \mathrm{~cm}$ between the two skins that reduces the heat loss from the bottom of the still to the ambient. The efficiency of the proposed concept has the capacity to reach about $70 \%$ for days with high solar irradiation. The best efficiency correspond to the highest global heat transfer coefficient and especially to the maximal evaporation rate. Thus, it can be concluded that all improvement made on the solar still's configuration that lead to accelerate the evaporation process has a greatest effect on the enhancement of efficiency. The obtained theoretical results for the improved solar still are compared to the study of Sarray et al. [17], which has been carried out to investigate the heat and mass transfer for a simple solar still device in Tunisia. A remarkable increase in the water temperature is obtained due to the transferred heat energy by convection from the tray to the water film $\left(\mathrm{q}_{\mathrm{c}, \mathrm{t}-\mathrm{w}}\right)$. The tray receives the heat energy from the absorbed solar radiation $\left(\alpha_{t}^{\prime} \times G(t)\right)$ and from the transmitted water vapor by forced convection using the fan $\left(\mathrm{q}_{\mathrm{fc}, \mathrm{v}-\mathrm{t}}\right)$. Therefore, the rise of the tray temperature especially between 11:00 am and 3:00 pm, leads to an increase in the temperature of water, which flows with very low depth. The new condensation process has a significant effect on minimizing the condensation heat loss from the cover to the ambient. Likewise, the major part of the condensation energy is reserved and reintroduced into the process with the aim of enhancing the productivity of the system as it may be clearly concluded from Fig. 3. The daily outputs are; $5 \mathrm{~L} / \mathrm{m}^{2}$.d for the conventional solar still and $8.4 \mathrm{~L} / \mathrm{m}^{2}$.d for the new 
configuration. Thus, the daily productivity enhancement of the proposed solar still is around $68 \%$. The second condensation process achieved under the tray is the result of the high temperature difference between the transferred water vapor and the inner surface of the basin $\operatorname{liner}\left(\mathrm{T}_{\mathrm{v}}-\mathrm{T}_{\mathrm{bi}}\right)$. Furthermore, the condensation energy is passed forward by convection to the tray, than to the brine water, thereby an accelerated evaporation process is achieved.

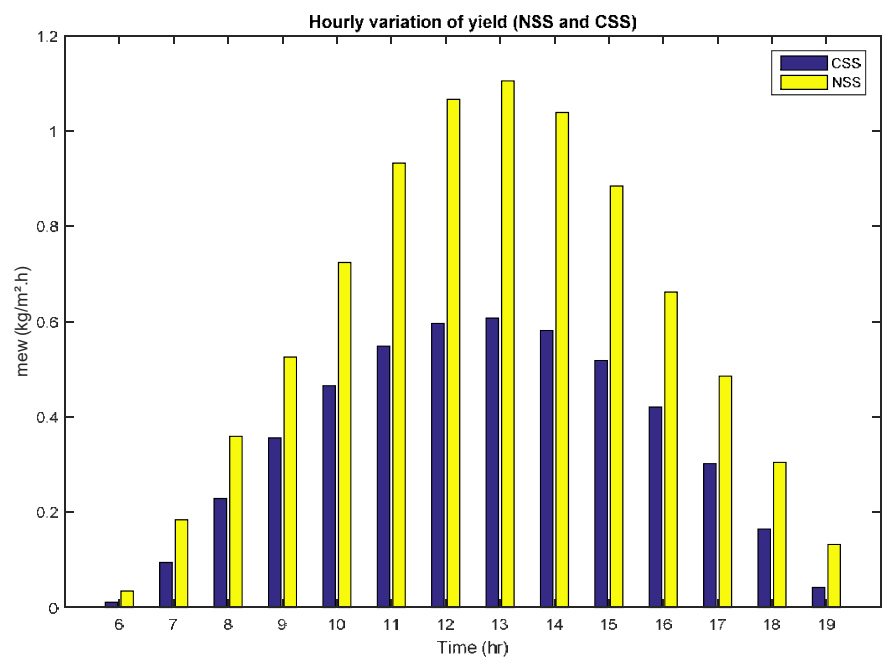

Figure 3: Hourly variation of yield of the conventional solar still (CSS) and the new solar still (NSS).

\section{DESIGN OF EXPERIMENTS FOR THE NEW SOLAR STILL OPTIMISATION}

DoE can be defined as an experimental optimization approach used to study multiple variables simultaneously and identify their influence on the output in an efficient way and with a reduced number of performed experiments [20]. Some of the most used DoE methods are: Full Factorial Design, Fractional Factorial Design, Analysis of Variance (ANOVA), Taguchi method and Response Surface Modelling (RSM) [21]. In order to improve its productivity and efficiency, many researchers have focused on investigating the influence of various parameters on the solar still's performance using several design of experiments methods. In the present study, the selected design of experiment method is the Taguchi method. The choice of the Taguchi method is based on the simplicity and the efficiency of this method in building a robust experimental plan. Furthermore, the Taguchi approach gives the opportunity to develop designs for studying variation caused by noise factors, which are usually ignored in the others DoE approaches [22]. This research is interested in applying the proposed Taguchi design method to optimize six control factors with three levels each. These parameters are; type of the transparent cover (A), distance between the evaporation and condensation surfaces (B), water salinity (C), angle of inclination (D), inlet water flow (E) and fan velocity $(\mathrm{F})$. In order to investigate the effect of noise sources on the productivity of the system, it will be needed to conduct each run of experiment once, for each combination of noise factors. The noise factors are; the wind velocity $(\mathrm{G})$, the ambient temperature $(\mathrm{H})$ and the solar intensity (I). Taguchi orthogonal array can include two matrices. The design matrix (or inner array) is the matrix reserved to the control factors setting and, the noise matrix (or outer array) is the matrix of the uncontrollable factors [23]. Table 1 illustrates the 
completed orthogonal array using L27 inner array and L4 outer array. After the experimental runs and data collection, the analysis of the results is the final step of Taguchi method. The data analysis aims to determine the optimal levels for all the control factors and to identify the most effective factors in reaching the high productivity of the system.

Table 1: Taguchi's orthogonal array.

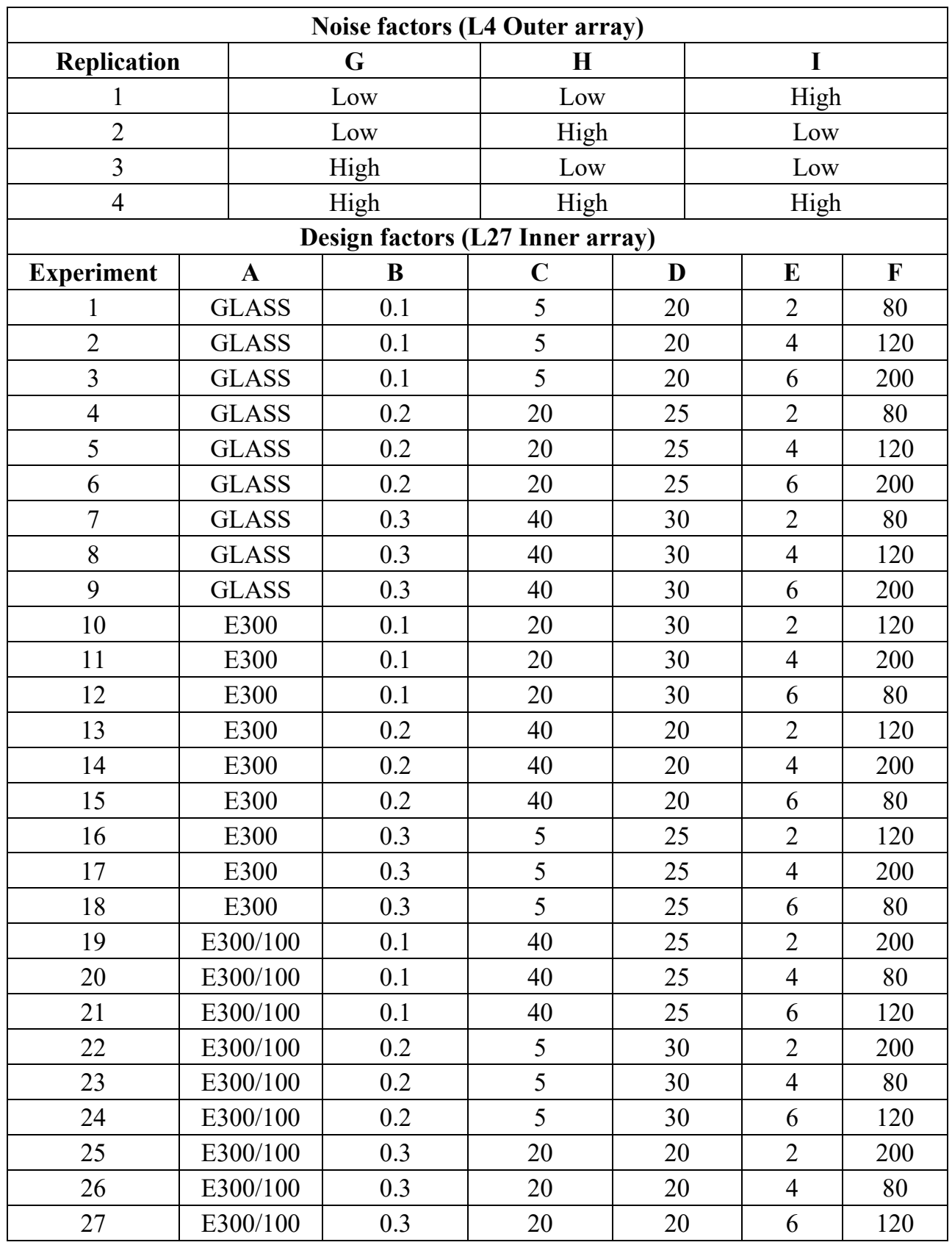




\section{CONCLUSION AND FUTURE WORK}

This study presents a new solar still configuration based on using an alternative cover material, a modified condensation process and thermodynamics. The proposed solar still is an economical and eco-friendly device enabling to produce a good quality of drinking water and to overcome the limited yield of the conventional solar still with maintaining a simple technology and low cost. A theoretical thermal model was performed in this study, based on developing an energy balance equations system for the different parts of the proposed solar still. The obtained results showed a great enhancement in the productivity of the proposed solar still compared to the simple device. Likewise, a design of experiment model was developed, using the Taguchi approach. This technique aims to build an efficient plan of experimentation. As a future scope of work, an experimental investigation will be carried out, as well as, an extensive validation of the theoretical model will be fulfilled by comparing the simulation results against experimental data. The validated model will offer the possibility to estimate the productivity of the enhanced device in any place in the world based on the meteorological data. On the other hand, the experiments will be conducted according to the trial conditions specified in Taguchi's orthogonal array. The analysis of the results will be performed in order to identify the most effective factors in reaching the highest yield.

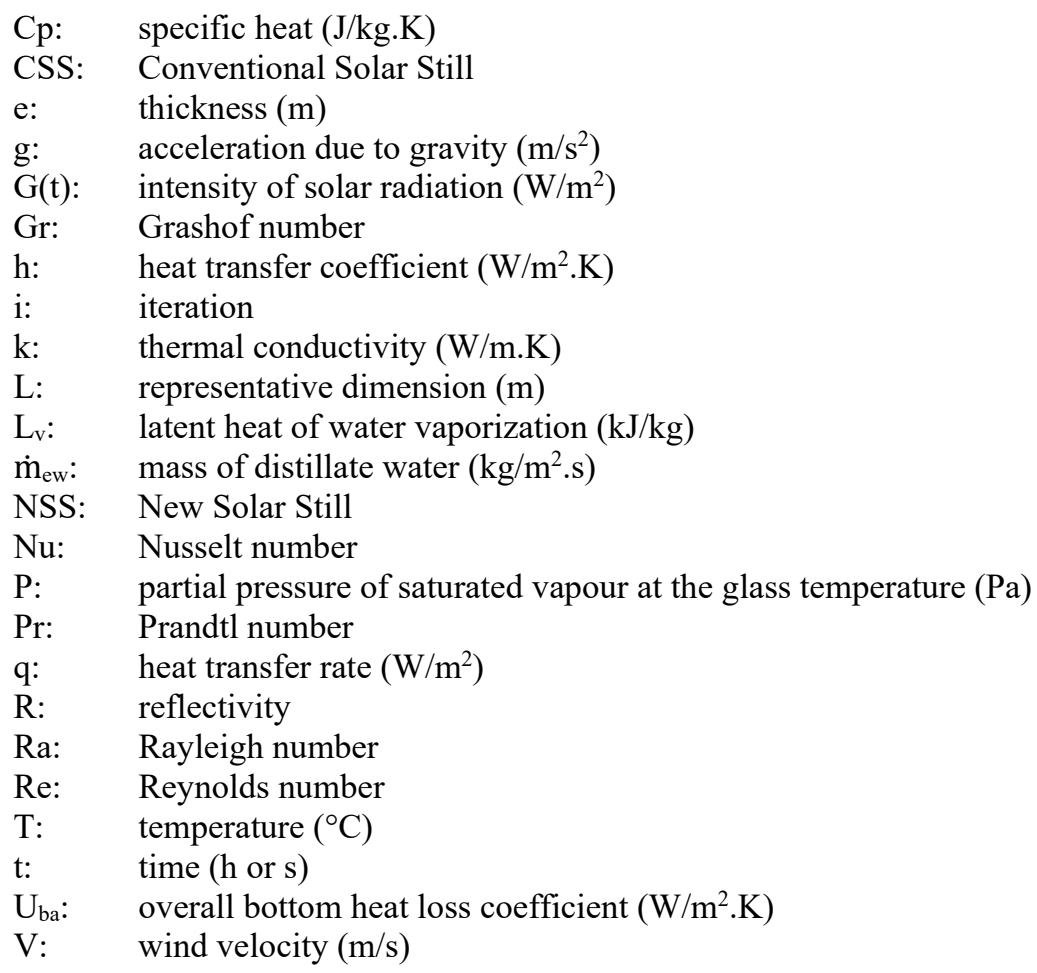

\section{Greek letters}

$\alpha$ : $\quad$ absorptivity

$\alpha^{\prime}: \quad$ fraction of absorbed solar radiation

$\beta$ : $\quad$ coefficient of volumetric expansion coefficient $\left(\mathrm{K}^{-1}\right)$

$\rho: \quad$ density $\left(\mathrm{kg} / \mathrm{m}^{3}\right)$ 


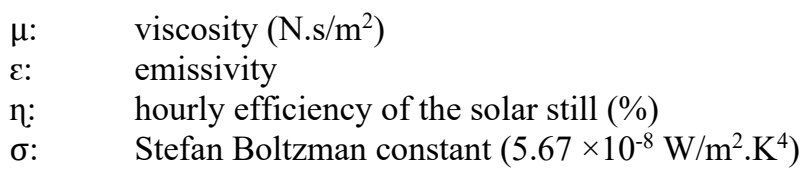

\section{Subscripts}

$\begin{array}{ll}\text { a: } & \text { ambient } \\ \text { b: } & \text { basin liner } \\ \mathrm{c}: & \text { convection } \\ \text { cd: } & \text { conduction } \\ \text { e: } & \text { evaporation } \\ \text { E: } & \text { ETFE } \\ \text { f: } & \text { forced convection } \\ \text { i: } & \text { insulating material } \\ \mathrm{r}: & \text { radiation } \\ \mathrm{s}: & \text { sky } \\ \mathrm{t}: & \text { tray } \\ \mathrm{v}: & \text { vapor } \\ \mathrm{w}: & \text { water }\end{array}$

\section{REFERENCES}

[1] Kalogirou, S.A., Seawater desalination using renewable energy sources. Progress in Energy Combustion Science, 31, pp. 242-281, 2005.

[2] Ahsan, A. \& Fukuhara, T., Mass and heat transfer model of tubular solar still. Solar Energy, 84, pp. 1147-1156, 2010.

[3] Boukar, M. \& Harmim, A., Parametric study of a vertical solar still under desert climatic conditions. Desalination, 168, pp. 21-28, 2004.

[4] Arun Kumar, T. et al., An experimental study on a hemispherical solar still. Desalination, 286, pp. 342-348, 2012.

[5] Omara, Z.M., Kabeel, A.E. \& Abdullah, A.S., A review of solar still performance with reflectors. Renewable and Sustainable Energy Reviews, 68, pp. 638-649, 2017.

[6] Madhlopa, A. \& Johnstone, C., Numerical study of a passive solar still with separate condenser. Renewable Energy, 34, pp. 1668-1677, 2009.

[7] El-Sebai, A., Thermal performance of a triple-basin solar still. Desalination, 174, pp. 23-37, 2005.

[8] Mahdi, J.T., Smith, B.E. \& Sharif, A.O., An experimental wick-type solar still system: Design and construction. Desalination, 267, pp. 233-238, 2011.

[9] Panchal, H., Sadasivuni, K.S., Israr. M. \& Thakar, N., Various techniques to enhance distillate output of tubular solar still: A review. Groundwater for Sustainable Development, 9, art. 100268, 2019.

[10] Harris, P., Kragh, M. \& Hogg, C., Energy modelling of ETFE membranes in building applications. Eleventh International IBPSA Conference, Glasgow, Scotland, 27-30 July, 2009.

[11] Robinson-Gayle, S., Kolokotroni, M., Cripps, A. \& Tanno, S., ETFE foil cushions in roofs and atria. Construction and Building Materials, 15, pp. 323-327, 2001.

[12] DeBergalis, M., ETFE foil is a co-polymer of ethylene and Teflon. Fluoropolymer films in the photovoltaic industry. Journal of Fluorine Chemistry, 125, pp. 1255-1257, 2004. 
[13] Elango, C., Gunasekaran, N. \& Sampathkumar, K., Thermal models of solar still: A comprehensive review. Renewable and Sustainable Energy Reviews, 47, pp. 856-911, 2015.

[14] Dunkle, R.V., Solar water distillation: the roof-type still and a multiple effect diffusion still. International Developments in Heat Transfer, ASME, pp. 895-902, 1961.

[15] Agrawal, A., Rana, R.S. \& Srivastava, P.K., Heat transfer coefficients and productivity of a single slope single basin solar still in Indian climatic condition: Experimental and theoretical comparison. Resource-Efficient Technologies, 3, pp. 466-482, 2017.

[16] Gaur, M.K. \& Tiwari, G.N., Optimization of number of collectors for integrated PV/T hybrid active solar still. Applied Energy, 87, pp. 1763-1772, 2010.

[17] Sarray, Y., Hidouri, N., Mchirgui, A. \& Ben Brahim, A., Study of heat and mass transfer phenomena and entropy rate of humid air inside a passive solar still. Desalination, 409, pp. 80-95, 2017.

[18] Boutriaa, A. \& Rahmani, A., Thermal modeling of a basin type solar still enhanced by a natural circulation loop. Computers and Chemical Engineering, 101, pp. 31-43, 2017.

[19] Holman, J.P., Empirical and practical relations for forced convection heat transfer. Heat Transfer, 10th ed., McGraw-Hill: New York, Chapter 6, 2010.

[20] Gordon, S., Design of experiments. Modeling and Simulation in the Systems Engineering Life Cycle. Simulation Foundations, Methods and Applications, ed. M. Loper, Springer: London, 2015.

[21] Tanco, M., Viles, E. \& Pozueta, L., Comparing different approaches for design of experiments (DoE). Advances in Electrical Engineering and Computational Science: Lecture Notes in Electrical Engineering, vol. 39, eds S.I. Ao \& L. Gelman, Springer: Dordrecht, 2009.

[22] Tarawneh, M., Rajendra Sethupathi, P.V. \& Senthil, P., Parametric optimization for improving the performance of single slope solar still through experimental studies. International Journal of Engineering Sciences and Research Technology, 5(9), 2016.

[23] Anitha, A., Arunachalam, S. \&Radhakrishnan, P., Critical parameters influencing the quality of prototypes in fused deposition modelling. Journal of Materials Processing Technology, 118, pp. 385-388, 2001. 